\title{
The Implementation of Liability Accounting on Managerial Performance in PT. Telkom Tbk, Medan Branch
}

\author{
Yuni Syahputri ${ }^{1}$, Teddi Pribadi ${ }^{2}$, Hasbiana Dalimunthe ${ }^{3}$ \\ ${ }^{1,2,3}$ Department of Accounting, Universitas Medan Area, Indonesia \\ yunisyahputri@staff.uma.ac.id
}

\begin{abstract}
This study aims to examine the effect of the application of responsibility accounting on managerial performance. The sample used in this study were 35 respondents. Data obtained by purposive sampling method. Data collection was carried out using a questionnaire. A total of 35 questionnaires were sent and 35 questionnaires were returned. The research hypothesis was tested using a simple regression method with the help of SPSS (Statistical Product and Service Solutions). Based on the results of this study, it can be concluded that the application of responsibility accounting has a significant effect on managerial performance.
\end{abstract}

Keywords

accountability, accounting, managerial performance

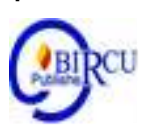

\section{Introduction}

Economic development is essentially aimed at improving people's welfare, increasing income and economic growth in all sectors of development, optimal equitable development, expanding the workforce and increasing the standard of living of the community. In achieving development objectives as a whole, there is a need for increased economic growth and equitable distribution of income.

PT. Telekomunikasi Indonesia Medan focuses on the field of information and communication services. As a large company, PT. Telekomunikasi Indonesia Medan must have good company management in order to provide good service to the public and also be able to compete in the current era of globalization. As previously explained, to be able to face the increasingly fierce competition in the business world requires company managers to be able to continue to improve their performance. Likewise with PT. Telekomunikasi Indonesia, Tbk Medan, the managers of this company are also required to have good performance in order to achieve company targets so that they can face today's world competition. In addition to managerial, it requires an accountability accounting system so that the resulting performance can be measured by comparing realization with budget. In connection with the descriptions above, the writer finds several phenomena.

The managerial performance of PT. Telekomunikasi Indonesia, this field can be stated as not very good, unstable in the last few years, sometimes it has increased and sometimes it has decreased. Human Resources (HR) at PT. Telekomunikasi Indonesia, Medan, are still slow in responding to any changes that occur such as the fast development of technology and science, one of which is influenced by constraints on training programs or seminars conducted by employees, sometimes not in accordance with the employee job description. Therefore, it is necessary to supervise the performance appraisal of the proposed and reported performance. The benefits of supervision are used to determine what activities have been or have not been carried out, evaluate and correct them with the intention of carrying out activities in accordance with the plans or programs that have been prepared in order to achieve company goals. Apart from the need for supervision, staffing and monitoring are needed to provide direction, guide, train, lead, develop subordinates and explain work 
regulations to subordinates, explain work objectives and handle employee complaints. This managerial performance problem causes the company's products to be unable to compete with old players such as Siemens or new players such as Nexian, Esia, and other new products. So that customers experience a decline which has an impact on profits or sales decline in 2016-2017. It can be seen that there is a decrease in the income of PT. Telekomunikasi Indonesia Medan from 2016 to 2017. The second phenomenon of PT. Telekomunikasi Indonesia in Medan in 2017 occurred in its managerial performance, namely the application of its reward system for employees who were not effective, lack of rewards for employees who performed well., problems with salary increases, allowances, overtime pay, commissions and others. A bad work environment and wages that do not meet employee standards can also result in employees in the company being less maximal in carrying out their work optimally, not spurring employees to work well.

This has resulted in service quality problems for service users who have not met consumer standards. There are complaints about the use of the services used, causing inconvenience for service users. Based on this problem, the possibility of a link with managerial performance at PT Telekomunikasi Indonesia Medan in 2017 which has been implemented is deemed unsatisfactory. So that the profit target at PT. Telekomunikasi Indonesia Medan is not achieved properly. (Source: www.bisnis.com). The following is attached PT.Telkom.Tbk profit and loss data for the period 2016 to 2018 where there was a decrease in company income before tax.

Based on the background described by the author above, the authors are interested in conducting research on, "The Effect of the Application of Responsibility Accounting on Managerial Performance at PT.Telkom, Tbk Medan."

\section{Review of Literature}

\subsection{Definition of Managerial Performance}

The definition of performance is a description of the level of achievement of the implementation of an activity program or policy in realizing the goals, objectives, vision and mission of the organization as outlined in the strategic planning of an organization. There are several definitions of managerial performance that have been put forward by experts, but first the definition of performance will be explained as follows:

According to Moeheriono (2009: 60) the definition of performance is as follows: "Performance is a description of the level of achievement of the implementation of an activity program or policy in realizing the goals, objectives, vision and mission of the organization."

Performance is the result that has been achieved from what has been done by the owner or manager in running the business. Marketing performance can be measured by using sales growth, customer growth and product success to measure the impact of the strategy adopted by the company. The company's strategy is always directed to produce good marketing performance and also good financial performance. The company's strategy is always directed to produce good marketing performance and also good financial performance because the business objectives besides creating customers, are also able to get profits. (Marlizar, 2020)

\subsection{Managerial Performance Indicators}

Mahoney (1963) in Kurnianingsih and Indriantoro (2013: 24) explains, measuring managerial performance with the following indicators:

1. "Planning 
Actions based on facts and assumptions that will come in order to achieve the desired goal.

2. Investigation

Efforts are made to collect and prepare information in the form of reports. Records and work analysis to be able to measure the results of its implementation.

3. Coordination

Aligning actions which include exchanging information with people in other organizational units, in order to be able to relate and adjust the program to be run.

4. Evaluation

Assessment of proposed and observed performance or performance.

5. Supervision

Directing, leading and developing the potential of subordinates as well as training and explaining work rules to subordinates.

6. Staffing

Maintaining and maintaining subordinates in a work unit, selecting new jobs, placing and promoting these jobs in other units.

7. Negotiation

Enterprises to obtain agreements in terms of purchases, sales or contracts for goods and services.

8. Representation

Delivering information about the vision, mission and activities of the organization by attending business group meetings and consulting with other companies. "

\subsection{Definition of Responsibility Accounting}

There are several opinions regarding the definition of responsible accounting (Responsibility Accounting), among others expressed by Garisson, Noreen and Brewer (2008: 380), namely: "Responsibility Accounting is a system of accountability in which managers are held responsible for those items of revenue and cost - and only those items over which the manager can exert significant control. The managers are held responsible for differences between budgeted and actual result. "Responsibility accounting is an accounting system in which managers are burdened with revenues and costs which are their responsibility and which are under their control. Managers are responsible for the difference between budget and realization"

\subsection{Responsibility Accounting Indicators}

According to Hansen and Mowen (2015: 229) that the purpose of responsibility accounting is to influence behavior in a certain way so that a person or company activity will be adjusted to achieve common goals. The benefits of responsibility accounting according to Mulyadi (2007: 413) are:

1. As a basis for budgeting.

Responsibility accounting information is useful for clarifying the role of a manager because in budgeting, it is determined who or which party is responsible for the implementation of activities to achieve the company's goals, also determines the resources (arranged in currency) provided to the holder of the responsibility for carrying out these activities. .

2. As an assessment of the performance of each accountability center manager. Performance appraisal is an assessment of human behavior in carrying out the role they have in the organization, if accounting information is one of the bases for performance appraisal, the information is related to management accounting which is 
linked to individuals who have roles in the organization which is management accounting information.

3. Manager motivation.

Motivation is the process of initiating a conscious and purposeful action. Motivation is something that is used to encourage someone's initiative to take action consciously and with purpose. In a corporate reward system, accounting information is an important part. A person will be motivated to work if he believes that his performance will be rewarded, giving rewards for performance will have a direct effect on the motivation of managers to improve performance.

\subsection{Conceptual Framework}

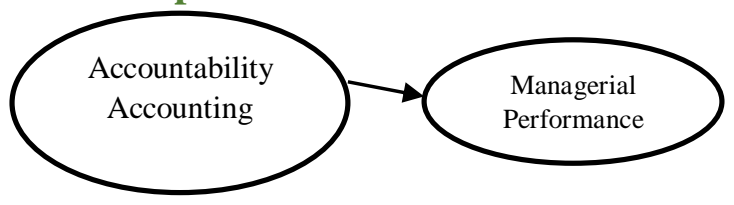

Figure 1 Conceptual Framework

\subsection{Hypothesis}

Hypothesis According to Suharsimi Arikunto (2013: 112) the hypothesis is: "Hypothesis is a statement that has an important position in research, therefore research requires its ability to be able to formulate this hypothesis clearly." Based on the literature review and the above framework, the authors formulate the following research hypothesis: "Responsibility accounting affects managerial performance."

\section{Research Method}

\subsection{Data Analysis Descriptive Statistics}

According to Sugiyono (2017: 8) quantitative research is the type of research based on the philosophy of positivism, is used to research on certain populations or samples, data collection uses research instruments, data analysis is quantitative or statistical, with the aim of testing predetermined hypotheses. The research method used by researchers is a quantitative method.

This research was conducted from December 2018 at Telkom.Tbk Office J1 Prof.HM.Yamin No: 21 Medan City, North Sumatra. The research period was conducted from December 2018 to April 2019.

\section{Result and Discussion}

\subsection{Data Analysis Descriptive Statistics}

Description of research variables is used as initial information in analyzing the results of respondents' answers. In this section, descriptive statistics of the independent and dependent variables will be presented. The variables used in this study are accountability accounting and work performance. The following are the results of descriptive statistics from the data used in this study: 
Table 1. The results of descriptive statistics from the data

\begin{tabular}{llllll}
\hline Variable & $\mathrm{N}$ & Minimum & Maximum & Mean & Std. Deviation \\
\hline Accounting & 35 & 32 & 50 & 60.55 & 3.58381 \\
Accountability & 35 & 40 & 55 & 64,34 & 3.80689 \\
Managerial & & & & & \\
Performance & & & & & \\
\hline
\end{tabular}

Based on the results of data processing in Table 1 above, it can be seen that the responsibility accounting variable from the respondents' answers obtained an average (mean) of 60.55, meaning that many respondents agreed on the statements from the questionnaire related to responsibility accounting with a standard deviation of 3.58381. The lowest value of the responsibility accounting variable of 32 indicates that there are respondents who answered strongly disagree with the statements in the questionnaire related to accountability accounting and the highest value of 50 indicates that there are respondents who answer strongly to the questions in the questionnaire related to accountability accounting.

\subsection{Classic Assumption Test}

The classic assumption test is used to see or test whether a model is feasible or not suitable for use in research. The classic assumption tests used in this study are:

Tabel 2. One-Sample Kolmogorov-Smirnov Test

\begin{tabular}{|ll|l|}
\hline & & Unstandardized Residual \\
\hline $\mathrm{N}$ & & 35 \\
Normal Parameters & a Mean & .0000000 \\
& Std. Deviation & 3.25959294 \\
Most Extreme & Absolute & .139 \\
Differences & Positive & .073 \\
& Negative & -.139 \\
& Kolmogorov-Smirnov Z & .821 \\
Asymp. Sig. (2-tailed) & .510 \\
\hline
\end{tabular}

In Table 2, it can be seen that the Asymp. Sig. (2-tailed) is 0.510 and above the significance value (0.05), this means that the data residual variables are normally distributed.

\subsection{Hypothesis Testing}

a. F test (simultaneous test)

The F test is carried out to see together (simultaneously) the effect of the variables (X1, $\mathrm{X} 2$ ) in the form of the responsibility accounting variable on managerial performance (Y).

Tabel 3. F-Test

\begin{tabular}{|l|l|l|l|l|l|}
\hline Model & $\begin{array}{l}\text { Sum of } \\
\text { Squares }\end{array}$ & df & Mean Square & F & Sig. \\
\hline Regression & 131.495 & 1 & 131.495 & 12.012 & $.001^{\mathrm{a}}$ \\
Residual & 361.248 & 33 & 10.947 & & \\
Total & 492.743 & 34 & & & \\
\hline
\end{tabular}




\begin{tabular}{|l|l|l|l|l|l|}
\hline \multicolumn{2}{|c|}{ ANOVA $^{\mathrm{b}}$} & & Sig. \\
\hline Model & $\begin{array}{l}\text { Sum of } \\
\text { Squares }\end{array}$ & df & Mean Square & F & Sig. \\
\hline Regression & 131.495 & 1 & 131.495 & 12.012 & $.001^{\mathrm{a}}$ \\
Residual & 361.248 & 33 & 10.947 & & \\
Total & 492.743 & 34 & & & \\
\hline
\end{tabular}

a. Predictors: (Constant), Akuntansi

Pertanggungjawaban

b. Dependent Variable: Kinerja

Manajerial

Based on Anova (Table 3), the calculated F value is 12.012 with a significant level (Sig.) Of 0.000a. So F count $>$ F table (12.012> 3.29) or significance (Sig.) $<5 \%(0.000$ $<0.05)$ means that the responsibility accounting variable has a positive and significant effect on the managerial performance of PT Telkom Indonesia, TBk which means that Ho is rejected Ha accepted.

\section{Conclusion}

Based on the results and discussion that has been done previously, the conclusion that can be drawn is, the application of responsibility accounting has a significant effect on managerial performance. This research is in line with research conducted by Putri (2015), Viyanti and Tin (2010) and Rena (2012). This is because the value of $t$ is greater than $t$ table (3.466> 2.034) and is significant at 0.001 . This proves that the hypothesis in this study can be accepted.

Thus, the greater the application of responsibility accounting, the more it will improve managerial performance. Where the results of this analysis are different from previous research conducted by Lestari (2011) that the application of responsibility accounting has no effect on managerial performance which may be influenced by differences in the respondents studied, the time and area of the study. So that activities carried out in different environments, organizations with different goals, sizes and organizational structures, and people inside or outside the organization can produce different results.

\section{Suggestion}

The suggestions from researchers are related to some of the above limitations, including:

1. Further research is expected not only to depend on the results of the questionnaire, but also to conduct in-depth interviews with each respondent " so as to obtain more accurate data as well as to improve the quality of data processing results.

2. Further research is expected to use respondents at manager level and assistant manager with as much as possible according to the responsibility center in order to better know the differences from the research results.

3. Further research is expected to use other companies as research objects or to use companies engaged in the same field but different areas in other big cities such as Surabaya, Malang, Bandung, and so on. So that the research results are more likely to be concluded in general. 


\section{References}

Abdullah, Firdaus Ahmad Dunia dan Wasilah. (2012). Akuntansi Biaya. Jakarta: Salemba Empat.

Andani, Kadek Novi. (2017). Analisis Pengaruh Penerapan Akuntansi Pertanggungjawaban terhadap Kinerja Perusahaan dengan Motivasi Kerja sebagai Variabel Moderasi. eJournal S1 Ak Universitas Pendidikan Ganesha Jurusan Akuntansi Program S1 (Volume: 7 No: 1 Tahun 2017)

Anik, Anggun Putri. (2013). Evaluasi Penerapan Akuntansi Pertanggungjawaban sebagai Alat Pengendalian Biaya Produksi. Jurnal EMBA 1667 Vol.1 No.4 Desember 2013, Hal. 1667-1676.

Ardiani, Ni Made Suari. Wirasedana, I Wayan Pradnyantha. (2010). Pengaruh Penetapan Akuntansi Pertanggungjawaban terhadap Efektifitas Pengendalian Biaya. ISSN: 23028556. E-Jurnal Akuntansi Universitas Udayana 5.3 (2013):561-573

Andani, Kadek Novi. (2017). Analisis Pengaruh Penerapan Akuntansi Pertanggungjawaban terhadap Kinerja Perusahaan dengan Motivasi Kerja sebagai Variabel Moderasi. eJournal S1 Ak Universitas Pendidikan Ganesha Jurusan Akuntansi Program S1 (Volume: 7 No: 1 Tahun 2017)

Anik, Anggun Putri. (2013). Evaluasi Penerapan Akuntansi Pertanggungjawaban sebagai Alat Pengendalian Biaya Produksi. Jurnal EMBA 1667 Vol.1 No.4 Desember 2013, Hal. 1667-1676.

Ardiani, Ni Made Suari. Wirasedana, I Wayan Pradnyantha. (2010). Pengaruh Penetapan Akuntansi Pertanggungjawaban terhadap Efektifitas Pengendalian Biaya. ISSN: 23028556. E-Jurnal Akuntansi Universitas Udayana 5.3 (2013):561-573

Arikunto, Suharsimi. (2013). Prosedur Penelitian Suatu Pendekatan Praktik. Jakarta: Rineka Cipta.

Bambang Wahyudi. (2012). Manajemen Sumber Daya. Jakarta: Bumi Aksara.

Basri. A. F. M., dan Rivai, V. 2015. Performance Appraisal. Jakarta: PT Raja Grafindo Persada

Carter, William K dan Usry, Mitton F. (2009). Akuntansi Biaya II. Edisi 14. Jakarta: Salemba Empat.

Dewi, Yunita Sari. (2009). Penerapan Akuntansi Pertanggungjawaban pada Informasi Akuntansi sebagai Alat Penilaian Kinerja Manajer Pusat Biaya.

Dwijayanti, Arie. (2015). Implementasi Akuntansi Pertanggungjawaban terhadap Penilaian Kinerja Manajer Pusat Pendapatan.

Empat.

. (2015). Akuntansi Biaya II. Edisi 13. Jakarta: Salemba

Edward. (2012). Akuntansi Keuangan Menengah Berbasis PSAK. Buku 1. Jakarta: Salemba Empat

Fathoni, Abdurahmat. (2016). Organisasi dan Manajemen Sumber Daya Manusia. Jakarta: Rineka Cipta.

Garrison, Ray, Noreen, Eric dan Brewer, Peter. Managerial Accounting. (2008). 14th Edition.

Gareth. R. Jones and Jennifer M.George. (2008). Contemporary Management.

Ghozali, Imam. (2012). Aplikasi Analisis Multivariate dengan Program SPSS. Edisi ke 7. Semarang: Badan Penerbit Universitas Diponegoro.

Gujarati, D.N. (2012). Dasar-dasar Ekonometrika diterjemahankan Mangunsong, R.C. Buku 2 Edisi ke 5. Jakarta: Salemba Empat. 
Halim, Abdul dan Muhamad Syam Kusufi. (2014). Akuntansi Manajemen. Edisi 8 . Jakarta: Salemba Empat.

Handoko, T Hani. (2013). Manajemen Sumber Daya Manusia. Bandung: Salemba Empat.

Hansen dan Mowen. (2009). Akuntansi Manajemen. Edisi 8 diterjemahkan oleh Deny Arnos Kwary. Jakarta: Salemba Empat. . (2012). Akuntansi Manajemen. Edisi diterjemahkan oleh Deny Arnos Kwary. Jakarta: Salemba Empat. . (2015). Akuntansi Manajemen. Edisi . Jakarta: Salemba Empat.

Harrison, Walter T. Horngren, Charles T. Thomas, Bill dan Suwardy, Themin. (2011). Financial Accounting. 8th-Edition.

Hasibuan, Malayu S.P. (2011). Manajemen Sumber Daya Manusia. Jakarta: Bumi Aksara.

Hidayat, Taufik. (2012). Analisis Pengaruh Penerapan Akuntansi Pertanggungjawaban Terhadap Kinerja Manajer Pusat Laba di Warung Paskal Bandung. Jurnal Akuntansi Vol.4 No.2 November 2012: 187-199.

Hilarius Prima. (2014). Pengaruh Akuntansi Pertanggung jawaban terhadap Penilaian Kinerja Manajer pada Hotel berbintang Lima di daerah Istimewa Jogyakarta. . Jurnal Akuntansi Vol.1 No.1 November 2014: 177-189.

Ikhsan, Arfan dan Muhammad Ishak. (2015). Akuntansi Keperilakuan. Jakarta: Salemba Empat.

Lubis, Arfan Ikhsan. (2011). Akuntansi Keperilakuan. Edisi 2. Jakarta: Salemba Empat.

Marlizar. Et al. (2020). The Role of Market Orientation and Creativity in Affecting the Marketing Performance of Market Traders in Aceh Market Banda Aceh City. Budapest International Research and Critics Institute-Journal (BIRCI-Journal). P. 1114-1127

Mursyidi. (2010). Akuntansi Dasar. Cetakan ke-1. Bogor: Ghalia Indonesia.

Moeheriana. (2009). Pengukuran kinerja Berbasisi Kompetensi. Bogor: Ghalia Indonesia

Mulyadi. (2009). Akuntansi Biaya. Edisi 5. Yogyakarta: Sekolah Tinggi Ilmu Manajemen YKPN.

Nafarin, M. (2004). Penganggaran Perusahaan. Jakarta: Salemba Empat 